\title{
The evaluation of coated granules to mask the bitter taste of dihydroartemisinin
}

\author{
Yasser Shahzad $^{1 *}$, Syed Nisar Hussain Shah², Shabbar Atique ${ }^{3}$, Muhammad Tayyab Ansari², \\ Farooq Bashir ${ }^{3}$, Talib Hussain ${ }^{1}$
}
${ }^{1}$ Division of Pharmacy and Pharmaceutical Sciences, University of Huddersfield, Queensgate, Huddersfield, UK, ${ }^{2}$ Faculty of Pharmacy, Bahauddin Zakariya University, Multan, Pakistan, ${ }^{3}$ Institute of Advance Materials, Bahauddin Zakariya University, Multan, Pakistan

\begin{abstract}
The purpose of this study was to mask the bitter taste imparted by dihydroartemisinin (DHA) by the use of different coating materials. Trial-1 and trial-2 were conducted to prepare the DHA granules. The granules produced from trial-1 were irregular in shape and smaller in size while the trial-2 granules were more regular and larger in size. The granules obtained from both trials were then coated with two different coating methods, namely $\mathrm{A}$ and $\mathrm{B}$, depending upon coating material. The trial-2 granules showed better flow properties than trial-1 granules. In vitro dissolution studies in phosphate buffer at $\mathrm{pH} 6.8$ revealed that granules of trial-2B released only $34 \% \pm 3$ DHA in two minutes compared with trial-1A $(57 \% \pm 2)$, trial-1B $(48 \% \pm 2)$ and trial-2A $(53 \% \pm 7)$. The pleasant taste perception (PTP) test also confirmed the taste masking efficacy of trial-2B $(\mathrm{P}<0.05)$. Scanning electron microscopy (SEM) revealed the more regular and smooth surface of trial-2B granules. In addition, the differential thermal and thermogravimetric analysis (TG-DTA) confirmed no interaction between the materials and pure DHA. DHA has shown its characteristic peaks in the x-ray diffraction (XRD) patterns which were also prominent in all the granules. In conclusion, the granules obtained from trial-2B displayed considerable decrease in the bitter taste of DHA thereby fulfilling the purpose of this study.
\end{abstract}

Uniterms: Medicines/coating. Granules/coating. Dihydroartemisinin (DHA)/taste masking. Thermogravimetric analysis/medicines analysis. X-ray diffraction/medicines analysis.

O objetivo deste estudo foi o de mascarar o gosto amargo característico da diidroartemisinina (DHA) pelo uso de diferentes materiais de revestimento. Experimento-1 e experimento- 2 foram realizados para preparar grânulos de DHA. Os grânulos produzidos pelo experimento-1 mostraram-se irregulares e menores se comparados aos obtidos pelo experimento-2, que foram mais regulares e maiores. Os grânulos obtidos em ambos os experimentos foram, então, revestidos por dois métodos distintos de revestimento, designados como $\mathrm{A}$ e $\mathrm{B}$, dependendo do material de revestimento empregado. Os grânulos do experimento-2 mostraram melhor propriedade de fluxo que os obtidos no experimento-1. Estudos de dissolução in vitro em tampão fosfato $\mathrm{pH}$ 6,8 revelaram que grânulos do experimento-2B liberaram apenas $34 \% \pm 3$ da DHA em dois minutos se comparado com experimento- $1 \mathrm{~A}(57 \% \pm 2)$, experimento- $1 \mathrm{~B}$ $(48 \% \pm 2)$ e experimento-2A $(53 \% \pm 7)$. A Análise Sensorial quanto ao sabor (Pleasant Taste Perception PTP) também confirmou a eficácia do experimento-2B $(\mathrm{P}<0,05)$ em mascarar o gosto amargo da DHA. Microscopia Eletrônica de Varredura (SEM) revelou a superfície mais regular e lisa dos grânulos obtidos pelo experimento-2B. Além disso, Análise Termogravimétrica e Análise Térmica Diferencial (TG-DTA) confirmaram que não há nenhuma interação entre os materiais e a DHA pura. DHA mostrou seus picos característicos na Difração de Raios X (XRD) em padrões que também foram proeminentes em todas as amostras. Em conclusão, os grânulos obtidos pelo experimento-2B exibiram diminuição considerável no gosto amargo da DHA, o que era o propósito deste estudo.

Unitermos: Medicamentos/revestimento. Granulados/revestimento. Diidroartemisinina. Granulados. Análise termogravimétrica/análise de medicamentos. Difração de raio X/análise de medicamentos.

*Correspondence: Y. Shahzad. Division of Pharmacy and Pharmaceutical Sciences, University of Huddersfield, Queensgate Huddersfield, HD1 3DH, United Kingdom. Email: y.shahzad@hud.ac.uk 


\section{INTRODUCTION}

Bitter, astringent, metallic or unpleasant tastes are highly unacceptable if using the oral route of delivery, especially in the case of pediatric drugs (Roy, 1994; Szejtli, Szente, 2005). The majority of the orally administered drugs including alkaloids such as quinine, and antibiotics such as sparfloxacin or clarithromycin, are bitter in taste (Shirai et al., 1993, 1994; Katsuragi et al., 1995, 1997; Yajima et al., 1999). However, for patients, such drugs are not necessarily easy to swallow, resulting in non-compliance and a subsequent decrease in efficacy. To overcome this problem various techniques have been developed to mask the unpleasant and bitter taste of drugs including capsules, coated tablets, microencapsulation, complexation and chemical modification (Cuña et al., 1997; Barra et al., 1999). But in most cases, solid preparations like tablets and capsules are not recommended for pediatric patients, instead liquid preparations are used. It is known that only dissolved substances elicit taste sensation and substances which are completely insoluble in water are tasteless. In many cases, however, the drugs are so intensely bitter, that they are barely tolerable even at ppm levels (Szejtli, Szente, 2005).

The most effective method of achieving maximum taste masking is to coat the drug particles, thereby creating a physical barrier around the drug. This may be achieved using microencapsulation techniques such as spray-drying (Yajima et al., 1999; Wilson et al., 1994), spray-congealing (Shimano et al., 1995; Robson et al., 1999), coacervation (Chukuwu et al. 1991; Al-Omranm et al., 2002) or the solvent evaporation method (Hashimoto et al., 2002).

Dihydroartemisinin (DHA), a more water-soluble metabolite of artemisinin derivatives, is a safe and highly effective antimalarial analog of artemisinin (Chen et al., 2004). It is isolated from the traditional Chinese herb Artemisia annua, and recommended as a first-line anti-malarial drug with low toxicity (Dhingra et al., 2000). This drug has a very bitter taste and therefore serves as a model drug to evaluate taste-masking efficiency for several kinds of oral formulations.

In the present investigation, our goal was to prepare DHA granules using the wet granulation technique (Ameye et al., 2002) and to apply enteric coating by using different coating materials to mask the bitter taste of DHA. The influence of these coatings on the surface morphology of granules were then examined using scanning electron microscopy (SEM) as well as the influence on their dissolution behavior at $\mathrm{pH} 6.8$ of the oral cavity. In addition, the palatability of the granules was evaluated in a pleasant taste perception (PTP) test. Finally, differential thermal analysis (DTA), thermogravimetric analysis (TGA), and $\mathrm{X}$-ray diffraction (XRD), was used to investigate possible interactions between the components of the formulation.

\section{EXPERIMENTAL}

\section{Materials}

Dihydroartemisinin (DHA) was a gift sample from AMSON Vaccines \& Pharma (Pvt.) Ltd. Islamabad, Pakistan. Methocel ${ }^{\circledR}$ E5 was obtained from Dow Chemical Co., Midland. Opadry ${ }^{\circledR}$ was purchased from Colorcon, West Point, PA. Carbopol 934P was obtained from B.F Goodrich, Cleveland, OH, USA. Polyvinylpyrrolidone (PVP-K30) and isopropyl alcohol (IPA) were obtained from Fluka (Buchs, Switzerland). Acetonitrile was 99\% HPLC grade (Merck, Germany). All the chemicals and reagents were of analytical grade.

\section{Chromatographic conditions and analysis}

The DHA analysis was performed on a HPLC Gradient SPD 10 A (Schimadzu) with UV detector at $209 \mathrm{~nm}$. The HPLC was equipped with a $20 \mu \mathrm{L}$ loop Rheodyne injector. A symmetry C-18 column (Waters corporation, $5 \mu \mathrm{m}, 4.6 \mathrm{x} 150 \mathrm{~mm}$ i.d.) was used as the stationary phase. The mobile phase was prepared by mixing HPLC grade acetonitrile and water (milli-Q) in a 35:65 v/v ratio and vacuum filtering it through a $0.45 \mu \mathrm{m}$ nylon filter. Filtered solvents were degassed before use. The flow rate was set at $1.2 \mathrm{~mL} / \mathrm{min}$ (Ansari et al., 2009).

\section{Solubility studies}

The test samples were prepared in water with an excess amount of pure DHA and placed on an orbital shaker at $100 \mathrm{rpm}$ for five days in a temperature controlled room at $37^{\circ} \mathrm{C}$. Samples were centrifuged and withdrawn with a syringe equipped with a $0.40 \mu \mathrm{m}$ syringe filter. All samples were diluted and immediately analyzed with HPLC for drug content. Samples were prepared in duplicate (Ansari et al., 2009).

\section{Preparation of granules}

The wet granules of DHA were prepared using two trials in a laboratory-scale low-shear mixer. The formulation of each trial is given in Table I. The batch size was $500 \mathrm{~g}$ for each trial (trial-1: granulation with starch, PVP$\mathrm{K} 30$, and IPA in $100 \mathrm{~mL}$ of distilled water, and trial-2: granulation with Carbopol 934P, sodium metabisulphite, 
and methyl paraben sodium in $150 \mathrm{~mL}$ of distilled water). The impeller speed was set at $100 \mathrm{rpm}$ for $10 \mathrm{~min}$ in all the trials to mix the powders, then, during addition of the granulation liquid, the impeller speed was raised to $400 \mathrm{rpm}$ for 10 minutes to wet the whole powder mixture.

Finally, the granules were dried at a reduced pressure at $60^{\circ} \mathrm{C}$ with an impeller speed of $100 \mathrm{rpm}$ for $10 \mathrm{~s}$ every $100 \mathrm{~s}$, while tilting the bowl to move the granules increasing the surface exposed to the evaporation process. The drying time, as a function of the amount of water used, was 25 minutes for trial-1, and $30 \mathrm{~min}$ for trial-2. Therefore, the total granulation time was $45 \mathrm{~min}$ for trial-1, and $50 \mathrm{~min}$ for trial-2. The granules were spread out in thin layers in a tray allowing them to cool at room temperature, then collected and sieved as described in the following section.

TABLE I - Formulation of DHA granules

\begin{tabular}{cccc}
\hline \multicolumn{2}{c}{ Trial 1 } & \multicolumn{2}{c}{ Trial 2 } \\
\hline Ingredients & Quantity & Ingredients & Quantity \\
\hline DHA & $350 \mathrm{~g}$ & DHA & $350 \mathrm{~g}$ \\
Starch & $30 \mathrm{~g}$ & Carbapol & $25 \mathrm{~g}$ \\
PVP-K30 & $40 \mathrm{~g}$ & Sodium & $50 \mathrm{~g}$ \\
& & Metabisulphite & \\
IPA & $80 \mathrm{ml}$ & Methyl & $75 \mathrm{~g}$ \\
& & Paraben & \\
& & Sodium & \\
DI water & QS & DI water & QS \\
\hline
\end{tabular}

\section{Coating of granules}

Coating was undertaken to mask the bitter taste and to improve the aesthetic appeal of the formulated granules of DHA. For this purpose, two coating methods namely $A$ and $B$ were used to coat the granules of each trial-1 and 2 in conventional coating pans. In coating method A, Methocil ${ }^{\mathrm{TM}}$ E5 (60 g) was mixed in $250 \mathrm{~g}$ of IPA with fast stirring. Titanium dioxide $(6 \mathrm{~g})$ and talcum $(10 \mathrm{~g})$ were then dissolved in $50 \mathrm{~mL}$ of methylene chloride. Both the solutions were then mixed together for 10 minutes for uniformity and then filtered. In coating method $B$, Opadry ${ }^{\circledR}$ enteric $(30 \mathrm{~g})$ was mixed in methylene chloride $(50 \mathrm{~mL})$ and IPA (300 g) with fast stirring for 40 minutes. A small quantity of methylene chloride was added and mixed for another 10 minutes for uniformity and then filtered. The trials were designated as trial-1A \& trial-1B, and trial$2 \mathrm{~A} \&$ trial-2B based on the method of coating applied to each formulation respectively. A laboratory scale coating pan (SH-506, Taiwan) was used to coat the granules. The operating speed of pan was $20 \mathrm{rpm}$ with high atomization and slow air speed. The distance of the coating gun was 25 inches from the granules bed for efficient coating. The granules were dried after coating by blowing hot air.

\section{Characterization of Granules}

\section{Granule size distribution}

The granule size distribution was evaluated by sieve analysis, using a vibrating shaker (Octagon Digital, Endecotts, London, UK) at a medium vibration level for $15 \mathrm{~min}$ and three standard sieves (Scientific Instruments s.r.1., Milan, Italy) in the range $250-2000 \mathrm{um}$. The fractions were then collected and stored in desiccators at $30 \pm 2{ }^{\circ} \mathrm{C}$. The granulation tests were performed at least in duplicate and the mean of each particle size \pm standard deviation (S.D.) was then calculated.

\section{Rheological study of formulated granules}

The rheological properties of formulated granules were determined by Carr's index (Leon, et al., 1986):

$$
C=\frac{\rho_{t}-\rho_{p}}{\rho_{t}} \times 100
$$

Where $\rho_{\mathrm{p}}$ is the poured density described by mass of sample granules divided by the undistributed volume in a $10 \mathrm{~mL}$ cylinder after filling, and $\rho_{\mathrm{t}}$ is the tapped density described by mass of sample granules per unit volume after tapping a bed of granules, after no change of volume was observed.

\section{Drug content estimation}

The analysis of the DHA content in each fraction was carried out by dissolving $50 \mathrm{mg}$ of granules in $100 \mathrm{~mL}$ of phosphate buffer at $\mathrm{pH} 6.8$ (within the $\mathrm{pH}$ range of saliva); the amount of the drug was then determined by HPLC Gradient SPD 10 A (Schimadzu) at $209 \mathrm{~nm}$. Each fraction was analyzed in triplicate.

\section{In vitro dissolution studies}

In vitro dissolution tests were performed using the USP 24 paddle method (Pharmatest, Steinhein, Germany) rotating at $60 \mathrm{rpm}$. A volume of $900 \mathrm{~mL}$ of $\mathrm{pH} 6.8$ phosphate buffer was used at a temperature of $37 \pm 1{ }^{\circ} \mathrm{C}$ to evaluate the taste-masking efficiency of the granules. Each sample contained $35 \mathrm{mg}$ of DHA. The samples were taken at a pre-determined time and analyzed by HPLC Gradiant SPD 10 A (Schimadzu). The amount of drug dissolved was analyzed at $209 \mathrm{~nm}$. The dissolution tests were performed 
in triplicate and the three absorption values were averaged and their S.D. was then calculated.

\section{Pleasant taste perception (PTP) test}

The PTP test was performed by six volunteers at the Gustatory Evaluation Laboratory of the Institute of Biotechnology, Bahauddin Zakariya University Multan (Pakistan). The involvement of human volunteers in this study was ethically approved by the Gustatory Evaluation Laboratory of the Institute of Biotechnology, Bahauddin Zakariya University. To find a suitable concentration for the evaluation of the bitterness taste intensity during the comparative test, the perception and bitterness recognition threshold of pure DHA was evaluated as described previously (Beatrice et al., 2004).

To determine the threshold of bitterness, seven standard solutions of pure DHA in distilled water at different concentrations were prepared as follows:

I. $0.00 \%(\mathrm{w} / \mathrm{v})$; II. $0.01 \%(\mathrm{w} / \mathrm{v})$; III. $0.025 \%(\mathrm{w} / \mathrm{v})$; IV. $0.05 \%(\mathrm{w} / \mathrm{v}) ;$ V. $0.1 \%(\mathrm{w} / \mathrm{v})$; VI. $0.2 \%(\mathrm{w} / \mathrm{v})$ and VII. $0.4 \%(\mathrm{w} / \mathrm{v})$.

The volunteers were then asked to taste $5 \mathrm{ml}$ of solution IV by keeping it in their mouth for 5 Seconds. Then, they were required to give one of these following perceptions:

1. "I feel a bitter taste".

2. "I do not feel any difference between solutions IV and I", 3. "I feel something but I can not identify the taste",

The volunteers whose answer perception was 2 or 3 were then asked to taste solution V (having a higher drug concentration than IV), while volunteers whose answer perception was 1 were then asked to taste solution III. The results yielded the perception threshold at $0.05 \%$ $(\mathrm{w} / \mathrm{v})$ (range $0.025-0.08 \%, \mathrm{w} / \mathrm{v})$ and bitterness recognition threshold at $0.08 \%(\mathrm{w} / \mathrm{v})$ (range $0.06-0.2 \%, \mathrm{w} / \mathrm{v})$. Subsequently, in order to have homogeneity in the sensation of the bitterness intensity among the volunteers, a trained panel evaluation was performed testing some solutions at different concentrations of DHA and the volunteers were told the bitterness scores (from 0 to 100) of these solutions.

The evaluation of the granules taste was then carried out by dispersing $250 \mathrm{mg}$ of each sample in $100 \mathrm{~mL}$ of water to obtain a $0.21 \%(\mathrm{w} / \mathrm{v}) \mathrm{DHA}$ granules suspension, which is higher than the bitterness recognition threshold. The granule particle size was the same as that used for the dissolution tests. The PTP test was performed on the granule suspension instead of the solid sample to evaluate if the in vitro drug release of the four samples could reflect upon the bitterness sensation after the same time ( $2 \mathrm{~min}$ ) and also to reduce the wide variability of drug concentration in the mouth, because of the different salivation conditions between volunteers, occurring when a solid sample is used.

The volunteers were then asked to taste $5 \mathrm{~mL}$ of each sample as previously described and to give a bitterness score (based on a $0.21 \%(\mathrm{w} / \mathrm{v})$ granule suspension bitterness score of 100). Significant differences among granules were analyzed using the unpaired student's t-test and a value of $P<0.05$ was considered significantly different.

\section{Scanning electron microscopy (SEM)}

The surface morphology of the developed formulations was examined using a scanning electron microscope (Hitachi S-6000).

\section{Differential thermal \& thermogravimetric Analysis (TG-DTA)}

The thermal stability of DHA granules was studied. For this, simultaneous TG-DTA experiments were performed using a Linesis STA PT 1600 instrument under an air flow of $100 \mathrm{~mL} / \mathrm{min}$ at heating rate of $5{ }^{\circ} \mathrm{C} / \mathrm{min}$ with an initial sample mass of $5 \mathrm{mg}$. Alumina crucibles were used for analysis.

\section{X-ray diffraction (XRD)}

X-ray powder diffraction (XRD) for DHA and granules was performed using a Bruker D8 Discover (Germany) apparatus. Measurement conditions included target $(\mathrm{CuK} \alpha)$, voltage ( $35 \mathrm{KV})$, and current ( $35 \mathrm{~mA})$. A system of diverging, receiving, and anti-scattering slits of $1^{\circ}, 1^{\circ}, 0.15^{\circ}$, respectively, were used. Eva software was used for the data processing (Evaluation Package Bruker, Germany). Patterns were obtained using a scan speed of 4 degree/minute with $2 \theta$ between $6^{\circ}$, and $35^{\circ}$ (Ansari et al., 2009).

\section{RESULTS AND DISCUSSION}

DHA granules were prepared by the conventional wet granulation method and characterized to confirm the suitability of granulation and coating method for reducing the unpleasant taste of the drug. DHA being a lipophilic drug showed low solubility in water as expected i.e. $0.12 \pm 0.01$ $\mathrm{mg} / \mathrm{mL}$. The result obtained is very similar to a previously reported result (Ansari et al., 2009). The Carr's index for trial-1 granules was 17.4 and 12.6 for trial-2 granules which indicates the better flowability of trial-2 granules as compared to trial-1 granules. Both the trials were designed to produce granules of better quality and to test the coating technique which favors more regular shaped granules. The 
granules produced from trial-1 were of smaller size mainly due to the addition of PVP (Beatrice et al., 2004). The granules produced from trial-2 were bigger in size than granules of trial-1. For trial-1, the cumulative frequency percent was 42 for granules having a size of $250 \mu \mathrm{m}, 35$ for $500 \mu \mathrm{m}$ and 22 were greater than $1000 \mu \mathrm{m}$, respectively (Figure 1). For trial-2, the cumulative frequency percent was only 19 for the $250 \mu \mathrm{m}$ size range, 43 for $500 \mu \mathrm{m}$ and 35 were greater than $1500 \mu \mathrm{m}$. Overall trial-2 yielded larger granules compared with trial-1. The yield of granules from granulation trial-1 and trial-2 was $94 \%(\mathrm{w} / \mathrm{w})$ and $95 \%(\mathrm{w} / \mathrm{w})$ respectively, which represents a very small loss of material during the granulation process.

Secondly, coating method A \& B were considered using SEM. Trial-1 A produced granules which were not sufficiently regular in shape to be considered ideal. This was also the case with the granules of trial-1B and trial-2A. However, coating method $\mathrm{B}$ when employed in trial-2 produced granules which were more regular in shape than any of the other trials (Figure 2). These granules were considered ideal for masking the bitter taste of DHA. The content of DHA in each fraction of trial-1 and trial-2 was also measured as described in the Methods section of this paper. Table 2 represents the actual amount of DHA in the formulated granules which was uniformly distributed in the range of 84 $-88 \%(\mathrm{w} / \mathrm{w})$ of the theoretical mass for both trials.

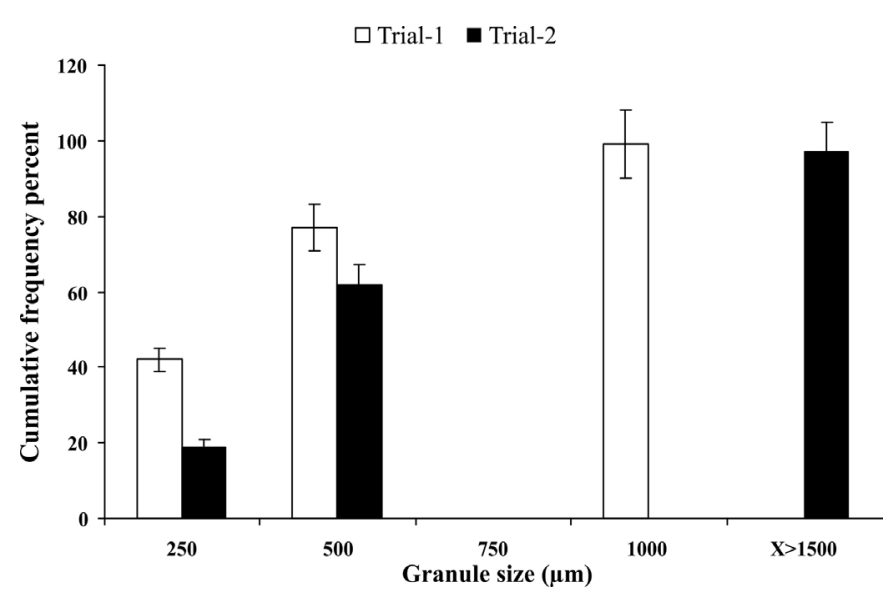

FIGURE 1 - Granule size distribution.
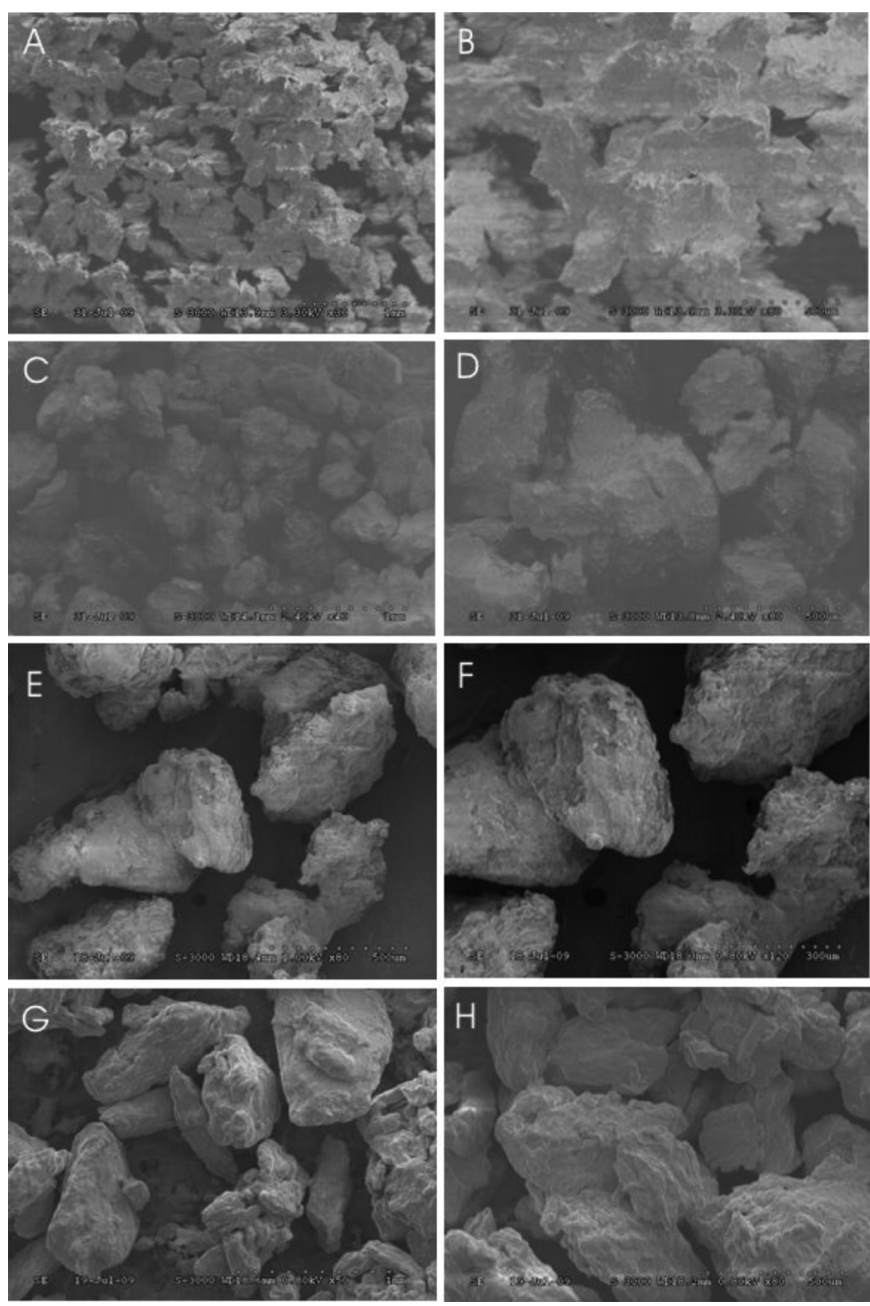

FIGURE 2 - SEM pictures of trial-1A (A) 30x and (B) 100x; trial-1B (C) 40x and (D) 80x; trial-2A (E) 80x and (F) 120x; trial-2B (G) 50x and (H) 80x.

The results of the pleasant taste perception test, performed by six volunteers, indicated that the taste-masking strategy is related not only to the granulation method but also the choice of coating material and formulation method. The trial-1A, trial-2A, trial-1B, and trial-2B granule solutions had bitter taste intensity scores of 87.5 (S.D. = 4.63; $P>0.05), 80.5$ (S.D. $=4.8 ; P>0.05), 74.16$ (S.D. $=3.14 ; P>0.05)$, and 47.33 (S.D. $=5.81 ; P<0.05)$, res-

TABLE II - Content of DHA granules as a function of particle size

\begin{tabular}{lccc}
\hline Size of Particles $(\mu \mathrm{m})$ & $\begin{array}{c}\text { Theoretical amount of DHA } \\
\text { per 50 mg of Granules }(\mathrm{mg})\end{array}$ & \multicolumn{2}{c}{ Actual amount of DHA calculated in mg* (\% drug Loading) } \\
\cline { 3 - 4 } & 35 & $29.97 \pm 0.97(84.48)$ & Trial-2 \\
\hline $250<\mathrm{x}<500$ & 35 & $29.51 \pm 1.01(84.31)$ & $30.44 \pm 0.78(86.97)$ \\
$500<\mathrm{x}<1000$ & 35 & $30.13 \pm 1.12(86.08)$ & $30.99 \pm 0.91(88.37)$ \\
$1000<\mathrm{x}<2000$ & &
\end{tabular}

"Values are given as mean \pm S.D 
pectively. These data confirm that the trial-2B granules successfully masked the bitter taste of DHA compared to the other formulations. The in vitro dissolution profiles of the granules were performed in phosphate buffer at $6.8 \mathrm{pH}$, which lies in range of saliva $\mathrm{pH}$ (6.2-7.4), and compared to those of pure DHA (Figure 3 ). The results comply with the findings of the PTP test. The dissolution of drug in 2 minutes is of particular interest as it suggests the dissolved amount is below the threshold of taste as observed in the PTP test. The dissolution profile of pure DHA was relatively high $(64 \% \pm 4$ at $2 \mathrm{~min})$ followed by trial-1A $(57 \% \pm$ $2)$, trial- $2 \mathrm{~A}(53 \% \pm 7)$, and trial-1B $(48 \% \pm 2)$. However the trial-2B formulation showed the lowest in vitro drug release and only $34 \% \pm 3$ was dissolved after 2 minutes. From the result, it is clear that trial-2B granules could represent the suitable pharmaceutical form to mask the bitter taste of DHA without modifying its release which was found to be almost $98 \%$ in all trial samples.

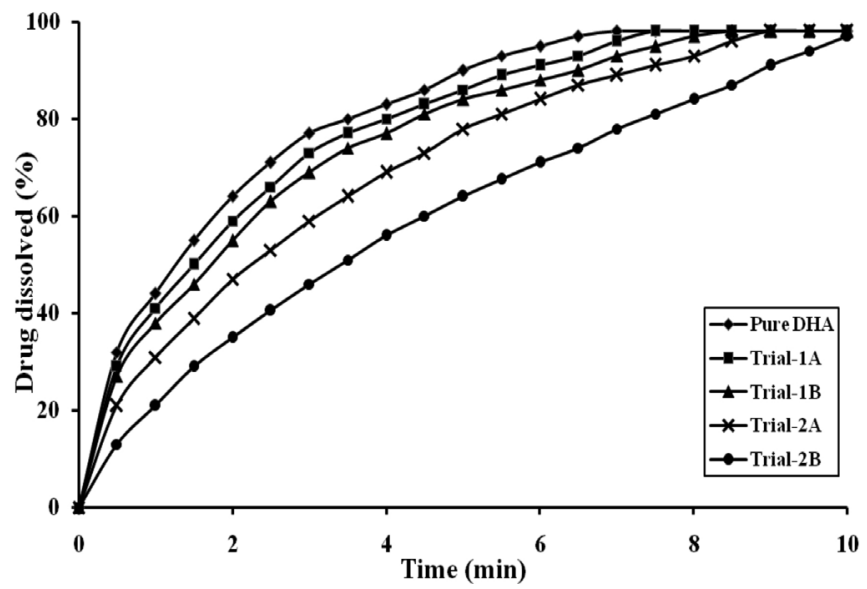

FIGURE 3 - In vitro dissolution profile of DHA granules.

To study the effect of formulation on the solid state of DHA, differential thermal analysis (DTA), thermogravimetric analysis (TGA) and $\mathrm{x}$-ray diffraction (XRD) studies were conducted. Thermal and gravimetric analyses were performed at a typical storage temperature of $30^{\circ} \mathrm{C}$ to reflect the climate where this research was conducted. The DTA curves (Figure 4) revealed the thermal stability of granules at the studied temperature confirming that from $30-125^{\circ} \mathrm{C}$, the granules are completely stable. The TG curves (Figure 5) for all granule trials were similar and with minimal decrease in weight from $30-125^{\circ} \mathrm{C}$. These results suggest that the granules have shown significant thermal stability in relation to the pure DHA.

XRD patterns display the characteristic peaks of DHA as described in earlier studies (Ansari et al., 2009). This confirms the presence of the crystalline form of DHA

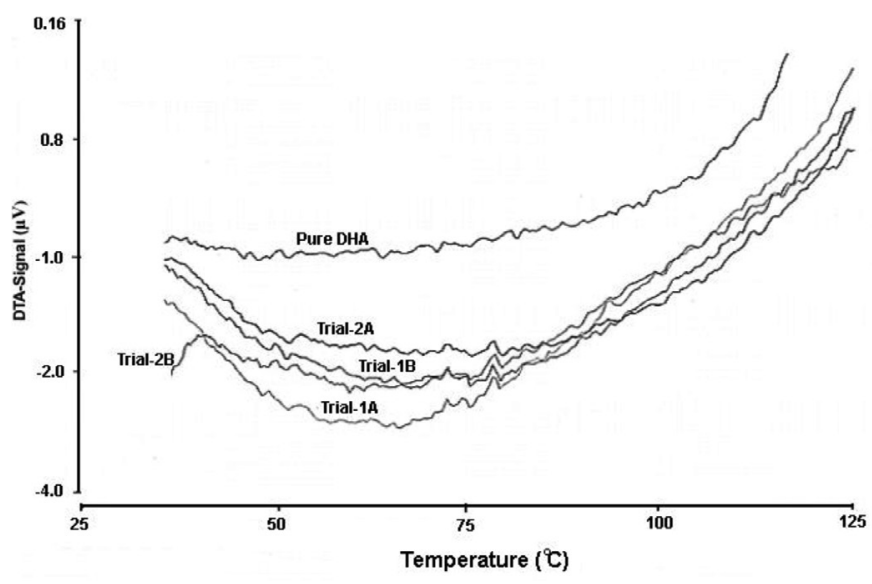

FIGURE 4 - DTA comparison of pure DHA and DHA granules.

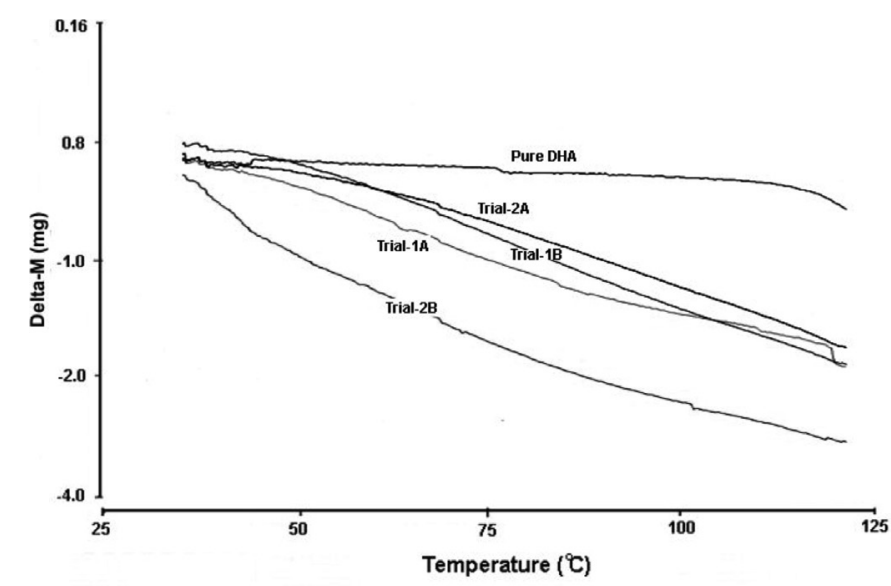

FIGURE 5 - TGA comparison of pure DHA and DHA granules.

and no phase transformations were seen in any of the formulations (Figure 6).

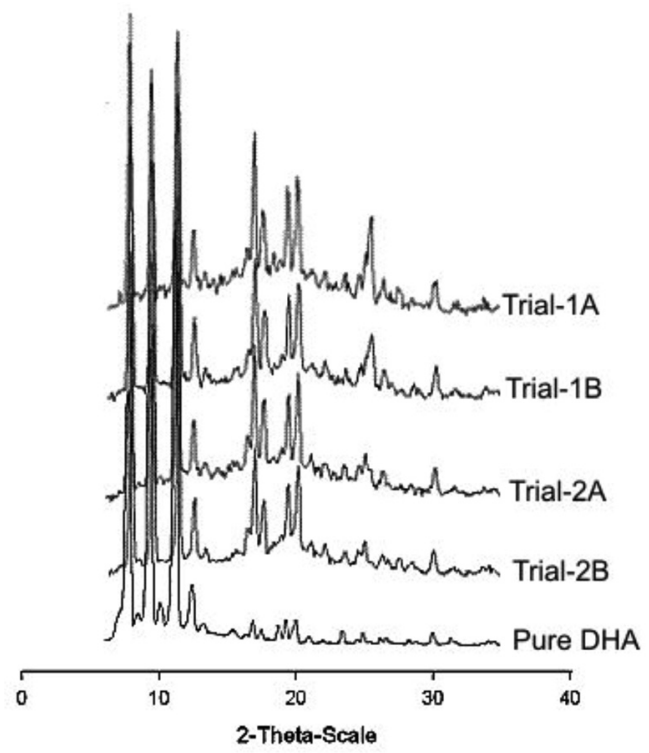

FIGURE 6 - XRD comparison of pure DHA and DHA granules. 


\section{CONCLUSION}

In conclusion, it was possible to reduce the bitterness of DHA using coating method B (coating material: Opadry enteric, methylene chloride and IPA) with granules of trial-2, confirmed by taste perception tests and in vitro dissolution testing. Trial-2 granules showed excellent flowability. The SEM showed a more regular coating on the surface of trial-2B granules which means an efficient coating on the surface of granules can inhibit the early escape of drug from granules resulting in less impart of bitter taste. The granules showed acceptable thermal stability and no phase transformations were revealed, therefore, no interaction was evident between the excipients and DHA itself. The present study has described a novel taste masking strategy which can possibly be used for other drugs in future studies.

\section{ACKNOWLEDGMENTS}

The authors would like to thank Prof. Dr Muhammad Ali Shah, Director of the Institute of Biotechnology, Bahauddin Zakariya University, Multan, for the pleasant taste perception test (ethically approved) and are also thankful to Mr. Waheed Ahmed for the helpful contribution to this research. Furthermore, authors extend their thanks to Bahauddin Zakariya University, Multan for providing funds to conduct this research.

\section{REFERENCES}

AL-OMRANM, M.F.; AL-SUWAYEH, S.A.; EL-HELW, A.M.; SALEH, S.I. Taste masking of diclofenac sodium using microencapsulation. J. Microencapsul., v.19, p.45-52, 2002.

AMEYE, D.; KELEB, E.; VERVAET, C.; REMON, J.P.; ADAMS, E.; MASSARAT, D.L. Scaling-up of a lactose wet granulation process in Mi-Pro High shear mixers. Eur. J. Pharm. Sci., v.17, p.247-251, 2002.

ANSARI, M.T.; IQBAL, I.; SUNDERLAND, V.B. Dihydroartemisinin-cyclodextrin Complexation: Solubility and Stability. Arch. Pharm. Res., v.32, p.155-165, 2009.

BARRA, J.; LESCURE, F.; DOELKER, E. Taste masking as a consequence of the organisation of powder mixes. Pharm. Acta Helv., v.74, p.37-42, 1999.
BEATRICE, A.; CRISTINA, C.; NADIA, P.; DARIO, V.; GONZÁLEZ-RODR'IGUEZ, M.L.; LORENZO, M.; LORENZO, R. Characterization and taste-masking evaluation of acetaminophen granules: comparison between different preparation methods in a high-shear mixer. Eur. J. Pharm. Sci., v.21, p.295-303, 2004.

CHEN, H-H.; ZHOU, H-J.; WANG, W-Q.; WU, G-D. Antimalarial dihydroartemisinin also inhibits angiogenesis. Cancer Chemother. Pharmacol., v.53, p.423-432, 2004.

CHUKWU, A.; AGARWAL, S.P.; ADIKWU, M.U. Some properties of chloroquine phosphate and quinine hydrochloride microcapsules. STP Pharm. Sci., v.1, p.117120, 1991.

CUÑA, M.; LORENZO-LAMOSA, L.M.; VILA-JATO, J.L.; TORRES D., ALOSO M.J. pH dependent cellulosic microspheres containing cefuroxime axetil: stability and in vitro release behaviour. Drug Dev. Ind. Pharm., v.23, p.259-265, 1997.

DHINGRA, V.; VISHWESHWAR, R.K.; LAKSHMI, N.M. Current status of artemisinin and its derivatives as antimalarial drugs. Life Sci., v.66, p.279-300, 2000.

HASHIMOTO, Y.; TANAKA, M.; KISHIMOTO, H.; SHIZOWA, H.; HASEGAWA, K.; MATSUYAMA, K.; UCHIDA, T. Preparation, characterization and tastemasking properties of polyvinylacetate microspheres containing trimebutine. J. Pharm. Pharmacol., v.54, p.1323-1328, 2002.

KATSURAGI, Y.; MITSUI, Y.; UMEDA, T.; OTSUJI, K.; YAMASAWA, S.; KURIHARA, K. Basic studies for the practical use of bitterness inhibitors: selective inhibition of bitterness by phospholipids. Pharm. Res., v.14, p.720724, 1997.

KATSURAGI, Y.; SUGIURA, Y.; LEE, C.; OTSUJI, K.; KURIHARA, K. Selective inhibition of bitter taste of various drugs by lipoprotein. Pharm. Res., v.12, p.658$662,1995$.

LEON, L.; LIBERMAN, H.A.; KANIG, J.L. The theory and practice of industrial pharmacy. 3.ed. Philadelphia: Lea \& Febiger, 1986. v.1, p.75-130. 
ROBSON, H.J.; CRAIG, D.Q.M.; DEUTSCH, D. An investigation into the release of cefuroxime axetil from taste-masked stearic acid microspheres. Part 1. The influence of the dissolution medium on the drug release profile and the physical integrity of the microspheres. Int. J. Pharm., v.190, p.183-192, 1999.

ROY, G.M. Taste masking in oral pharmaceuticals. Pharm. Tech., v.18, p.84-99, 1994.

SHIMANO, K.; KONDO, O.; MIWA, A.; HIGASHI, Y.; GOTO, S. Evaluation of uniform-sized microcapsules using a vibration-nozzle method. Drug Dev. Ind. Pharm., v.21, p.331-347, 1995.

SHIRAI, Y.; SOGO, K.; FUJIOKA, H.; NAKAMURA, Y. Role of low-substituted hydroxypropylcellulose in dissolution and bioavailability of novel fine granule system for masking bitter taste. Biol. Pharm. Bull., v.17, p.427-431, 1994.
SHIRAI, Y.; SOGO, K.; YAMAMOTO, K.; KOJIMA, K.; FUJIOKA, H.; MAKITA, H.; NAKAMURA, Y. A novel fine granule system for masking bitter taste. Biol. Pharm. Bull., v.16, p.172-177, 1993.

SZEJTLI, J.; SZENTE, L. Elimination of bitter, disgusting tastes of drugs and foods by Cyclodextrins. Eur. J. Pharm. BioPharm., v.61, p.115-125, 2005.

WILSON, M.L.; RITSHEL, W.A.; SAKR, A. Development of an ibuprofen lozenge for the elderly. Pharm. Ind., v.56, p.836-841, 1994.

YAJIMA, T.; UMEKI, N.; ITAI, S. Optimum spray congealing conditions for masking the bitter taste of clarithromycin in wax matrix. Chem. Pharm. Bull., v.47, p.220-225, 1999.

Received for publication on $26^{\text {th }}$ May 2010. Accepted for publication on $01^{\text {st }}$ July 2010. 